\title{
Driving forces of changes in the water and sediment relationship in the Yellow River
}

\author{
Shuai Wang ${ }^{\text {a,b }}$, Bojie Fu ${ }^{\text {a,b,*, Wei Liang }}{ }^{\text {a,b }}$, Yu Liu ${ }^{c}$, Yafeng Wang ${ }^{\text {a,b }}$ \\ a State Key Laboratory of Urban and Regional Ecology, Research Center for Eco-Environmental Sciences, Chinese Academy of Sciences, Beijing 100085, China \\ b Joint Center for Global Change Studies, Beijing 100875, China \\ c Key Laboratory of Ecosystem Network Observation and Modeling, Institute of Geographical Sciences and Natural Resources Research, Chinese Academy of Sciences, 100101 Beijing, China
}

\section{H I G H L I G H T S}

- A sediment identity approach to attribute different drivers was used.

- Sharp sediment reduction was mainly caused by a water yield decrease.

- Engineering and vegetation measures are responsible for majority of these reductions.

\section{G R A P H I C A L A B S T R A C T}

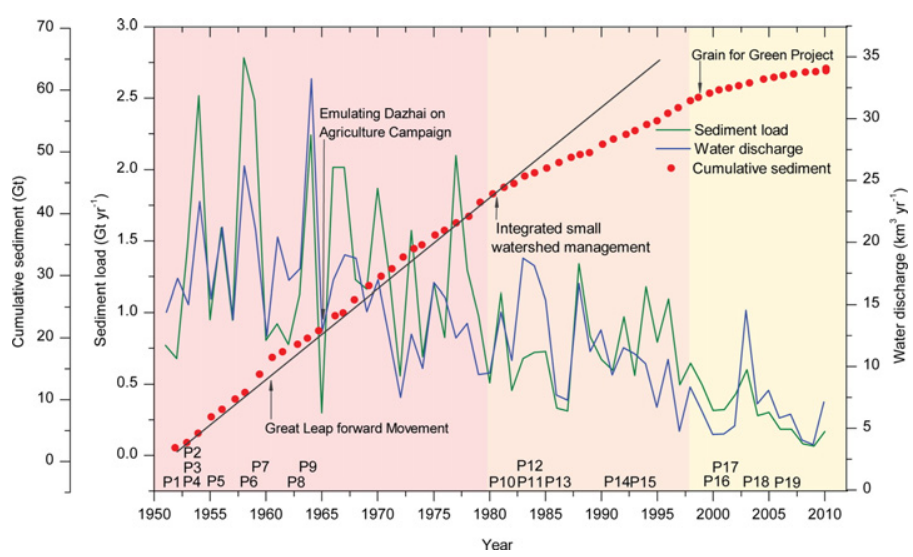

\section{A B S T R A C T}

The world is composed of various river basins. Within a specific river basin, water and sediment dynamics, and the relationship between them, can be assessed to reflect the basin's functions and services. Due to its changing nature, understanding and balancing the relationship between water and sediment is a global concern and is crucial for the sustainable management of river basins, especially for the Yellow River (YR), which is one of the most sediment-laden rivers in the world. Here, we used the past 60 years of runoff and sediment load observations to investigate the middle reach of the YR, i.e., the Loess Plateau (LP), the source of nearly $90 \%$ of the sediment load of the river. We found that a sharp (58\%) reduction of sediment after 1979 was mainly (59\%) caused by a water yield decrease. Engineering and vegetation measures have induced land surface modifications, which are responsible for $76 \%$ of the water reduction. These measures have been implemented as part of a coordinated set of soil and water conservation, and sediment control polices. We propose the cessation of such construction and the maintenance of a sustainable (i.e., minimal water consumption) vegetated ecosystem on the LP for soil conservation, and the establishment of an integrated basin-wide ecosystem and land use management regime for sustainable water use and sediment regulation.

(c) 2016 Elsevier B.V. All rights reserved.

\footnotetext{
* Corresponding author at: State Key Lab of Urban and Regional Ecology, Research Center for Eco-Environmental Sciences, Chinese Academy of Sciences, PO Box 2871, Beijing 100085, China.
} 


\section{Introduction}

River basins are relatively independent and naturally defined areas, but are also important locations for human habitation and socioeconomic development (Downs et al., 1991). The transportation of sediment through river runoff is an important feature that links the geomorphological processes of the upper and lower reaches of a basin, and is a key component in the functioning of the natural Earth system (Walling, 2009; Wang et al., 2016). Water discharge, sediment load, and the water-sediment relationship are affected by climate change and a range of human activities (Syvitski and Kettner, 2011; Wohl, 2006). Changes in water and sediment fluxes also have important socio-economic implications (Syvitski, 2003). Approximately 50\% of the world's rivers have shown significant decreasing trends in river sediment loads, while global river runoff has increased significantly during the 20th century (Piao et al., 2007; Walling and Fang, 2003). Therefore, understanding and balancing the relationship between water and sediment is a global concern and is crucial for the sustainable management of river basins (Kantoush and Sumi, 2010).

The Yellow River (YR) is well known worldwide due to its extraordinarily high suspended sediment concentration, which has earned it the name "Yellow", but it has a relatively low water discharge (Wang et al., 2016). Its annual sediment load peaked at about $1.6 \mathrm{Gt}$ in the middle of the last century, while the mean annual water discharge is only about $0.7 \%$ of the Amazon (with $0.4 \mathrm{Gt}$ sediment load) and $4.5 \%$ of the Yangtze (with 0.5 Gt sediment load) (Miao et al., 2010; Mu et al., 2012; Walling and Fang, 2003; Wang et al., 2006; Wang et al., 2007; Yu et al., 2013). Harmonizing the relationship between water and sediment has always been the most difficult aspect of YR management.

Decades of effort have reverted the YR sediment load to a near prehuman level that last occurred prior to 600 CE (Chen et al., 2015; Wang et al., 2016; Zhang et al., 2015). Since the 1970s, the amount of sediment transported by the YR has significantly declined (Yu et al., 2013; Zhang et al., 2015). In the middle reach of the YR, the current sediment flux across the Loess Plateau (LP) is less than one quarter of that before 1980 , and the average annual sediment load during 2000-2010 reduced

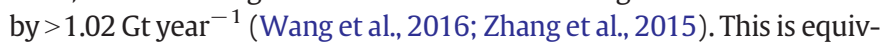
alent to the annual YR sediment input to the ocean in the 1980s (Zhang et al., 2015). The current sediment exported to the ocean at Lijin station is only $10.7 \%$ of the 1950 s level, due to the decline in sediment transportation (Yu et al., 2013). This is the combined result of water discharge and sediment concentration changes, while the water yield capacity of the river has also reduced dramatically over the same period (Wang et al., 2006). A reduced sediment concentration and flux can also give rise to problems due to the scouring of river channels and erosion of delta shorelines when the critical shear stress threshold is exceeded, as well as reducing nutrient inputs into aquatic and riparian ecosystems (Peng et al., 2010). Several studies have attempted to quantify the water and sediment trends of the YR and their driving forces (Miao and $\mathrm{Ni}$, 2009; Wang et al., 2006; Yu et al., 2013; Wang et al., 2015; Gao et al., 2016; Wang et al., 2016), and the synchronous decline of both the water and sediment flux suggests that the water and sediment relationship in the YR is stable. However, both the transport capacity of the YR water and sediment yield from the catchment have changed substantially due to climate change and intense human activities in recent decades (Kong et al., 2015; Miao et al., 2016), but the water and sediment relationship in the YR and its driving forces have seldom been discussed. In addition, although these studies have confirmed that the total amount of sediment and streamflow discharge have decreased in the middle reaches of the YR (Gao et al., 2016), a more detailed study of policy evolution and its effects on the relationship between water and sediment is needed. Therefore, the new discharge regime of the YR now needs to balance the water and sediment relationship for the whole basin. In this study, we focused on the LP in the middle reaches of the YR. The specific aims were: (i) to determine the temporal variations of water and sediment flux changes and their relationship between the entry and outlet stations, (ii) to estimate the relative contributions of precipitation, the water yield capacity of rainfall, and sediment concentration in runoff to sediment yield reduction during the last 60 years using the sediment identity for the LP, and (iii) to explore the spatial pattern of the driving forces of the main tributaries on the LP.

\section{Methods}

\subsection{Study area}

The YR basin is situated in the north of China, $\left(32^{\circ} \mathrm{N}-42^{\circ} \mathrm{N} / 96^{\circ} \mathrm{E}-\right.$ $\left.119^{\circ} \mathrm{E}\right)$, spanning $5500 \mathrm{~km}$ and encompassing an approximate area of $750,000 \mathrm{~km}^{2}$. The basin's climate is controlled by the continental monsoon circulation system and transits from semiarid and arid to subhumid and humid conditions. According to its distinct climatic, hydrological, and geomorphological characteristics, the YR is commonly separated into three major sections: the upper, middle, and lower reaches. The YR Basin covers many sub-reaches, but the water is mainly yielded from its upper reach in the Qinghai-Tibetan mountains ( 60\%), and sediment is mainly gained in the middle reach across the LP $(\sim 90 \%)$ (Fig. 1). The lower reach features a hanging river-bed and the vast

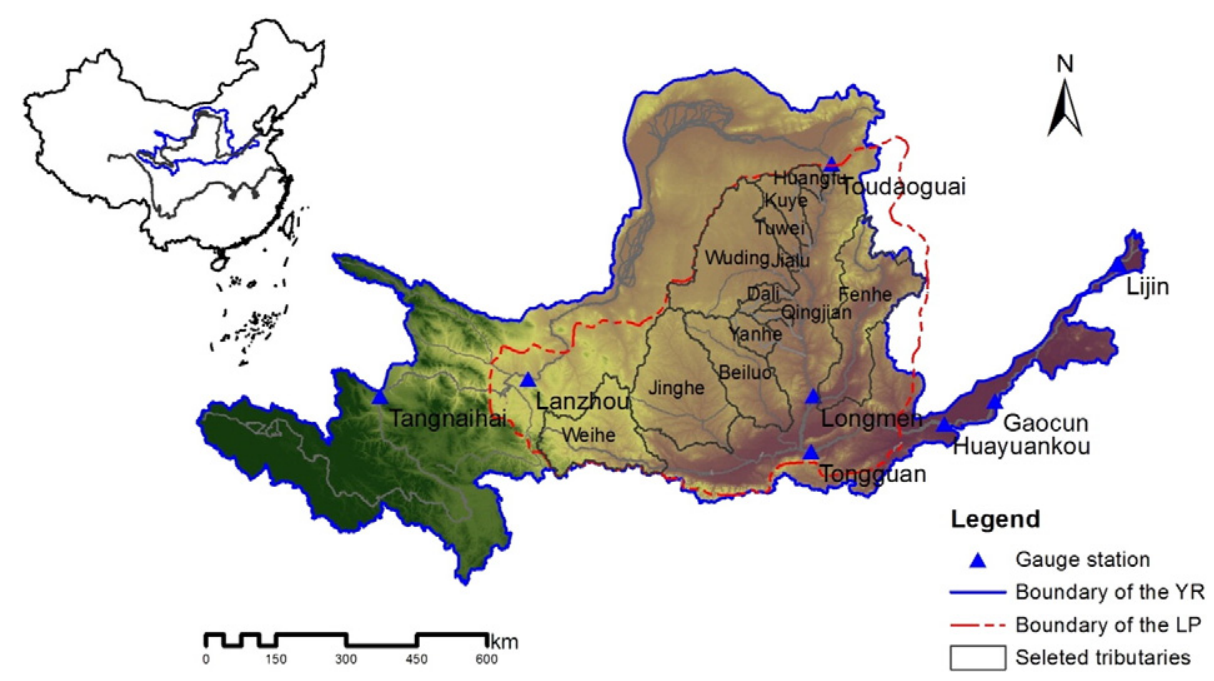

Fig. 1. Location of the Loess Plateau (LP) and the Yellow River (YR) Basin. 
alluvial plain of north China (Miao and Ni, 2009; Wang et al., 2006; Yu et al., 2013).

\subsection{Data}

Annual runoff and sediment load data from the main gauging stations along the YR and 12 tributaries on the LP (1951-2010) were obtained from the Bureau of Hydrology, Yellow River Conservancy Commission (YRCC). Daily meteorology data from 1951 to 2010 were provided by the National Meteorological Administration of China.

To fully reflect the hydrological characteristics of the basin, changes in precipitation $(\mathrm{P}, \mathrm{mm})$, potential evapotranspiration (PET, $\mathrm{mm}$ ), water discharge $\left(\mathrm{R}, \mathrm{km}^{3}\right)$, sediment load $(\mathrm{S}, \mathrm{Gt})$, sediment concentration $\left(\mathrm{SC}=\mathrm{S} / \mathrm{R}, \mathrm{kg} \mathrm{m}^{-3}\right)$, runoff coefficient $(\mathrm{Cr}=\mathrm{R} /$ (A.P), runoff depth ( $h=R / A, m m$ : where $A$ is the control area of a hydrological station, $\mathrm{km}^{2}$ ), and a soil erosion module, also known as sediment yield $\left(\mathrm{Em}=\mathrm{S} / \mathrm{A}, \mathrm{t} \mathrm{km}^{-2}\right.$ year $^{-1}$ ) (Liu et al., 2014) were analyzed. The daily potential evapotranspiration was calculated using the Food and Agriculture Organization (FAO) Penman-Monteith method with the mean, maximum, and minimum air temperatures; vapor pressure; relative humidity; wind speed at $2 \mathrm{~m}$; and bright sunshine hours obtained from the meteorological stations. The significance of the trends in annual meteorological and hydrological time series was estimated by the non-parametric Mann-Kendall (M-K) test. The non-parametric Pettitt breakpoint test was applied to detect abrupt changes in sediment transportation (Liang et al., 2015).

\subsection{Sediment identity factor assessment}

We used a sediment identity approach to attribute the change in river sediment load to different drivers. River sediment load was expressed as a product of three driving factors (Wang et al., 2016):

$S=P\left(\frac{R}{P}\right)\left(\frac{S}{R}\right)=\operatorname{PrS}$

where $\mathrm{S}$ is sediment load; $\mathrm{P}$ is precipitation; $\mathrm{R}$ is runoff; $r$ is water yield capacity (the ratio of river discharge to precipitation, also known as runoff ratio), which represents the water yield capacity of a catchment or region for a given precipitation; and $\mathrm{s}$ is sediment concentration (the ratio of annual sediment mass flux to discharge), which is correlated with the soil erosion, sediment delivery, and transport processes.

We then defined the proportional rate of change of a quantity $X(t)$ as $r(X)=X^{-1} d X / d t$. Because $\frac{d S / d t}{S}=\frac{d(P r s) / d t}{P r s}=\frac{d P / d t}{P}+\frac{d r / d t}{r}+\frac{d s / d t}{s}$, the counterpart of the sediment identity for proportional growth rates can be rewritten as:

$c(S)=r(P)+r(r)+r(s)$

For S, P, r, and s, we calculated their rate of change using a linear regression method, and normalizing them to their values in the prechange point period. The relative contribution of each factor was determined as the ratio of its proportional growth rate to the proportional growth rate of $\mathrm{S}$ during the same period.

\section{Results}

\subsection{Climate change trend}

We found that the LP has experienced a significant warming in recent decades $\left(0.22{ }^{\circ} \mathrm{C} /\right.$ decade, $p<0.01$, mean value of $\left.8.6^{\circ} \mathrm{C}\right)$, and precipitation has decreased slightly $\left(-1.2 \mathrm{~mm}\right.$ year $^{-2}, p=0.015$, mean value of $435 \mathrm{~mm}_{\text {year }}{ }^{-1}$ ), while the changes in potential evaporation across the LP did not display a significant trend (Liang et al., 2015). Precipitation in the main tributary basins ranged from $372 \mathrm{~mm}$ in Wuding to $527 \mathrm{~mm}$ in Jinghe, with all of them showing a decreasing trend, but this was only significant in the Fen River Basin $\left(-2.4 \mathrm{~mm}_{\text {year }}{ }^{-2}\right.$, $p=0.006$ ). In contrast, the potential evaporation capacity ranged from $999 \mathrm{~mm}$ in Jinghe to $1132 \mathrm{~mm}$ in Wuding, with most of them also showing a decreasing trend (except in the Wuding and Yan river basins), but again this was only significant in the Fen River Basin ($2.2 \mathrm{~mm} \operatorname{year}^{-2}, p=0.009$ ) (Table 2 ). In general, the LP region has been experiencing a climatic warming and drying trend since the 1950s, which displays a degree of spatial heterogeneity (Table 1 ).

\subsection{Trends in the water and sediment fluxes}

The average annual sediment load increased by $91 \%$ from Toudaoguai (TDG, point of entry to the LP) station $(1.04 \pm 0.67 \mathrm{Gt}$ year $\left.^{-1}\right)$ to Tongguan (TG, outlet of the LP) station $(0.09 \pm 0.67 \mathrm{Gt}$ year $^{-1}$ ), while the water discharge only increased by $38 \%$ from $21.39 \pm 7.46$ to $34.31 \pm 12.10 \mathrm{~km}^{3}$ year $^{-1}$. This indicates that the LP is the main contributor of the sediment transported to the YR, while the amount of water is limited. Both the water and sediment fluxes at these two stations have significantly decreased in recent decades. The sediment flux at TG $\left(-0.03 \mathrm{Gt}_{\text {year }}{ }^{-2}, p<0.001\right)$ was nearly ten times more than at TDG $\left(-0.003 \mathrm{Gt}\right.$ year $\left.^{-2}, p<0.001\right)$, and the water flow rate was nearly twice as high $\left(-0.46\right.$ and $-0.23 \mathrm{~km}^{3}$ year ${ }^{-2}$, respectively, $p<0.001$ ). Accordingly, the mass budget over the middle reach of the YR, which was obtained from the difference of the measured sediment flux and water discharge at TG and TDG was also found to have significantly decreased ( $p<0.001$ ), with values of 0.02 and $0.25 \mathrm{~km}^{3}$ year ${ }^{-2}$, respectively.

For the 12 tributary stations, the hydrological variables including both water and sediment flux displayed a significantly decreasing trend at most stations, as shown in Table 3. The decreasing trend of $\mathrm{R}$ was not significant at Qingjian $(p=0.10)$ and Jinghe $(p=0.05)$ at the 0.05 significance level. For sediment flux, the decreasing tend at Beiluo $(p=0.12)$ and Jinghe $(p=0.12)$ was not significant, but at Dali $(p=0.02)$ and Qingjian $(\mathrm{p}=0.05)$ it was significant at the 0.05 level. The tributaries with a decreasing trend in runoff depth of $>1$ mm year ${ }^{-2}$ were Weihe $(-1.77)$, Jialu $(-1.70)$, Kuye $(-1.65)$, Tuwei $(-1.64)$, and Huangfu $(-1.06)$. The tributaries with a decreasing trend of the erosion modulus or sediment yield $\left(=\mathrm{S} / \mathrm{A}, \mathrm{Mg} \mathrm{km}^{-2}\right.$ year $^{-2}$ ) of $>300 \mathrm{Mg} \mathrm{km}^{-2}$ year $^{-2}$ were Jialu $\left(-419 \mathrm{Mg} \mathrm{km}^{-2}\right.$ year $\left.^{-2}\right)$, Huangfu $\left(-331 \mathrm{Mg} \mathrm{km}^{-2}\right.$ year $\left.^{-2}\right)$, and Kuye $(-322 \mathrm{Mg}$ $\mathrm{km}^{-2}$ year $^{-2}$ ).

\subsection{Variations of water-sediment relationships}

The change point analysis results indicated that the change point year of annual sediment yield from the LP was 1979. The water discharge after the change point decreased by about $43 \%$ and the sediment load decreased by about $58 \%$. The sediment load displayed greater reductions than the water discharge. This inconsistency in the rate of change of the two parameters resulted in variations in the watersediment relationship, which was reflected in the sediment concentration. The sediment concentration in the river water at the TG station significantly $(p<0.01)$ decreased from $35.9 \pm 13.9 \mathrm{~kg} \mathrm{~m}^{-3}$ in the pre-

Table 1

The mean and trend of the water and sediment flux in the Loess Plateau. Toudaoguai (entrance), Tongguan (outlet), and net budget.

\begin{tabular}{|c|c|c|c|c|c|c|c|c|}
\hline \multirow[t]{2}{*}{ Location } & \multicolumn{4}{|l|}{$\mathrm{R}$} & \multicolumn{4}{|l|}{ S } \\
\hline & $\begin{array}{l}\text { Mean } \\
\left(\mathrm{km}^{3}\right. \\
\left.\text { year }^{-1}\right)\end{array}$ & $\begin{array}{l}\text { CV } \\
(\%)\end{array}$ & $\begin{array}{l}\text { Trend } \\
\left(\mathrm{km}^{3}\right. \\
\left.\text { year }^{-2}\right)\end{array}$ & $\mathrm{p}$ & $\begin{array}{l}\text { Mean } \\
(\mathrm{Gt} \\
\left.\text { year }^{-1}\right)\end{array}$ & $\begin{array}{l}\text { CV } \\
(\%)\end{array}$ & $\begin{array}{l}\text { Trend } \\
(\mathrm{Gt} \\
\left.\text { year }^{-2}\right)\end{array}$ & $\mathrm{p}$ \\
\hline Toudaoguai & 21.40 & 34.87 & -0.218 & 0.000 & 0.09 & 76.21 & -0.003 & 0.000 \\
\hline Tongguan & 34.31 & 35.29 & -0.464 & 0.000 & 1.04 & 64.85 & -0.025 & 0.000 \\
\hline $\begin{array}{l}\text { Loess } \\
\text { Plateau }\end{array}$ & 12.92 & 45.71 & -0.245 & 0.000 & 0.95 & 67.56 & -0.022 & 0.000 \\
\hline
\end{tabular}


Table 2

Main tributary catchment characteristics and the mean and trend of annual precipitation (P) and potential evapotranspiration (PET).

\begin{tabular}{|c|c|c|c|c|c|c|c|c|c|c|}
\hline \multirow[t]{2}{*}{ Catchment } & \multirow[t]{2}{*}{ Station } & \multirow[t]{2}{*}{ Area $\left(\mathrm{km}^{2}\right)$} & \multicolumn{4}{|l|}{$\mathrm{P}$} & \multicolumn{4}{|l|}{ PET } \\
\hline & & & Mean $\left(\mathrm{mm}\right.$ year $\left.^{-1}\right)$ & $\mathrm{CV}(\%)$ & Trend $\left(\mathrm{mm}\right.$ year $\left.^{-2}\right)$ & $\mathrm{p}$ & Mean $\left(\mathrm{mm}\right.$ year $\left.^{-1}\right)$ & $\mathrm{CV}(\%)$ & Trend $\left(\mathrm{mm}\right.$ year $\left.{ }^{-2}\right)$ & $\mathrm{p}$ \\
\hline Huangfu & Huangfu & 3230 & 406 & 24 & -0.95 & 0.351 & 1026 & 8 & -1.62 & 0.036 \\
\hline Kuye & Wenjiachuan & 8621 & 402 & 24 & -1.27 & 0.197 & 1075 & 7 & -0.97 & 0.234 \\
\hline Tuwei & Gaojiachuan & 3307 & 411 & 24 & -1.55 & 0.115 & 1093 & 8 & -0.13 & 0.874 \\
\hline Jialu & Shenjiawan & 1138 & 437 & 24 & -1.30 & 0.216 & 1093 & 11 & -0.19 & 0.882 \\
\hline Wuding & Dingjiagou & 24,682 & 373 & 25 & -0.83 & 0.376 & 1133 & 7 & 0.45 & 0.594 \\
\hline Dali & Suide & 3861 & 484 & 18 & -1.01 & 0.260 & 1110 & 10 & -0.99 & 0.390 \\
\hline Qingjian & Yanchuan & 3600 & 499 & 20 & -1.68 & 0.091 & 1084 & 15 & -0.03 & 0.984 \\
\hline Yan & Ganguyi & 5857 & 507 & 20 & -1.43 & 0.155 & 1072 & 10 & 0.15 & 0.891 \\
\hline Beiluo & Zhuangtou & 25,723 & 502 & 18 & -1.66 & 0.077 & 1049 & 8 & -0.29 & 0.727 \\
\hline Jing & Zhangjiashan & 43,106 & 527 & 18 & -1.91 & 0.045 & 1000 & 7 & -0.93 & 0.170 \\
\hline Wei & Linjiacun & 30,122 & 502 & 22 & -1.70 & 0.132 & 1015 & 8 & -1.12 & 0.158 \\
\hline Fen & Hejin & 38,728 & 515 & 17 & -2.39 & 0.006 & 1004 & 8 & -2.15 & 0.009 \\
\hline
\end{tabular}

change point period to $22.4 \pm 10.1 \mathrm{~kg} \mathrm{~m}^{-3}$ in the post-change point period, and the TDG station also experienced a decrease, although it was much less, ranging from $5.1 \pm 2.2$ to $2.6 \pm 1.1 \mathrm{~kg} \mathrm{~m}^{-3}$ ( $\left.p=0.56\right)$.

The annual precipitation-water discharge and water-sediment relationships for the pre and post-change point periods in the LP are shown in Fig. 2. All of these relationships fitted a linear function well, as indicated by the $\mathrm{R}^{2}$ values. The interception of water discharge and precipitation, and the slope of the regression lines of the relationship between sediment and water during the post-change point period were clearly lower than those during the pre-change point period. These imply both the capacity of precipitation yield water and sediment in the YR basin have decreased, but at different rates, so the relationship between water and sediment has changed.

Fig. 3a shows the relative contributions of precipitation, the water yield capacity of rainfall, and changes in sediment concentration in river flow to sediment load reduction after the change point using the sediment identity. Relative to the pre-change point period, the average relative rate of change of S across the LP was $-2.44 \%$ year $^{-1}$, with $12 \%$ of this decrease being explained by decreasing precipitation, $58 \%$ by a coincident reduction of runoff yield capacity, and the remaining 30\% being attributable to reduced sediment concentrations. We also identified two periods with an increasing s during the 1960s and 1980s in the temporal dynamic processes shown in Fig. 3b. Fig. 4 shows the spatial dynamics of the relative contributions of these three variables on the changes in sediment concentration in tributaries in the LP. It was also found that all three of these variables had a positive effect on sediment load reduction in the tributaries. The sediment identity analysis suggested that precipitation, runoff yield capacity, and sediment concentration trends contributed an average of $13.6 \pm 8.9,40.5 \pm 11.4$, and $46.33 \pm 14.9 \%$, respectively, of the observed decrease of sediment load. However, this was not homogeneous across the LP. For example, precipitation contributed $>36 \%$ in the Jinghe, $r$ contributed nearly $63 \%$ in the Huangfu, and s contributed $69 \%$ in the Wuding (Fig. 4). Fig. 5 shows the temporal dynamics of these processes.

The relative contributions of precipitation change and water yield capacity were quantitatively evaluated. On average, water yield capacity (76\%) contributed more than precipitation change (24\%) to the reduction of water discharge (Fig. 6). This is consistent $(r=0.95, p<0.001)$ with the results of two Budyko-based methods (the elasticity and decomposition methods) (Liang et al., 2015), but the identity method cannot consider the effects of rising temperature and accordingly the increased potential effect of evapotranspiration.

\subsection{Spatial variability}

Sediment transportation is an integrated indicator of a river basin function and the dynamic relationship of sediment with water also reflects its response to climate change and human disturbance (Walling and Fang, 2003). The 12 main tributaries on the LP have also displayed different hydrological behaviors in recent decades (Fig. 7). During the pre-change point period, they contributed $67 \%$ of the sediment and $64 \%$ of the total water discharge from the LP. The Jinghe $(18 \%)$ and Weihe (17\%) tributaries were the largest contributors of sediment and water, respectively. The reduction of sediment and water from these 12 tributaries accounted for $65 \%$ of the total sediment and $74 \%$ of the total water reduction from the LP. The Kuye (15\%) and Weihe (20\%) tributaries accounted for most of these reductions. These results are integrated reductions in the magnitude of sediment and water yield capacity across their control area. For runoff depth and erosion modulus,

Table 3

The mean and trend of the water and sediment variables in the main tributaries in the Loess Plateau.

\begin{tabular}{|c|c|c|c|c|c|c|c|c|c|c|c|c|c|c|c|c|}
\hline \multirow[t]{2}{*}{ Catchment } & \multicolumn{4}{|l|}{$\mathrm{R}$} & \multicolumn{4}{|l|}{ S } & \multicolumn{4}{|l|}{ h } & \multicolumn{4}{|l|}{ Em } \\
\hline & $\begin{array}{l}\text { Mean } \\
\left(\mathrm{km}^{3}\right. \\
\left.\text { year }^{-1}\right)\end{array}$ & $\begin{array}{l}\mathrm{CV} \\
(\%)\end{array}$ & $\begin{array}{l}\text { Trend } \\
\left(\mathrm{km}^{3}\right. \\
\left.\text { year }^{-2}\right)\end{array}$ & $\mathrm{p}$ & $\begin{array}{l}\text { Mean (Gt } \\
\left.\text { year }^{-1}\right)\end{array}$ & CV (\%) & $\begin{array}{l}\text { Trend (Gt } \\
\text { year }^{-2} \text { ) }\end{array}$ & $\mathrm{p}$ & $\begin{array}{l}\text { Mean } \\
(\mathrm{mm})\end{array}$ & $\begin{array}{l}\mathrm{CV} \\
(\%)\end{array}$ & $\begin{array}{l}\text { Trend } \\
(\mathrm{mm} \\
\left.\text { year }^{-2}\right)\end{array}$ & $\mathrm{p}$ & $\begin{array}{l}\text { Mean }\left(10^{4} \mathrm{t}\right. \\
\left.\mathrm{km}^{-2} \text { year }^{-1}\right)\end{array}$ & CV (\%) & $\begin{array}{l}\text { Trend }\left(10^{4} \mathrm{t}\right. \\
\left.\mathrm{km}^{-2} \text { year }^{-2}\right)\end{array}$ & $\mathrm{p}$ \\
\hline Huangfu & 0.12 & 79.66 & 0.00 & 0.00 & 0.04 & 102.01 & 0.00 & 0.01 & 37.00 & 79.66 & -1.06 & 0.00 & $11,379.85$ & 100.47 & -331.94 & 0.00 \\
\hline Kuye & 0.52 & 54.31 & -0.01 & 0.00 & 0.07 & 103.73 & 0.00 & 0.00 & 60.11 & 54.31 & -1.65 & 0.00 & 8826.78 & 101.59 & -322.18 & 0.00 \\
\hline Tuwei & 0.32 & 28.43 & -0.01 & 0.00 & 0.01 & 112.53 & 0.00 & 0.00 & 88.70 & 30.82 & -1.64 & 0.00 & 4733.64 & 111.84 & -174.29 & 0.00 \\
\hline Jialu & 0.06 & 64.37 & 0.00 & 0.00 & 0.01 & 129.34 & 0.00 & 0.00 & 48.43 & 64.37 & -1.70 & 0.00 & $10,113.82$ & 127.22 & -419.11 & 0.00 \\
\hline Wuding & 0.86 & 25.39 & -0.01 & 0.00 & 0.03 & 110.09 & 0.00 & 0.00 & 34.94 & 25.39 & -0.50 & 0.00 & 1386.74 & 110.09 & -60.55 & 0.00 \\
\hline Dali & 0.14 & 33.61 & 0.00 & 0.00 & 0.03 & 85.23 & 0.00 & 0.02 & 36.60 & 33.61 & -0.36 & 0.00 & 6984.15 & 85.23 & -169.98 & 0.02 \\
\hline Qingjian & 0.14 & 39.94 & 0.00 & 0.10 & 0.03 & 90.89 & 0.00 & 0.05 & 38.30 & 68.29 & -0.43 & 0.10 & 7867.02 & 90.89 & -165.27 & 0.05 \\
\hline Yan & 0.20 & 37.49 & 0.00 & 0.00 & 0.04 & 90.54 & 0.00 & 0.01 & 34.04 & 37.49 & -0.36 & 0.00 & 6201.14 & 90.54 & -172.88 & 0.01 \\
\hline Beiluo & 0.61 & 41.17 & -0.01 & 0.00 & 0.06 & 85.76 & 0.00 & 0.12 & 35.00 & 28.08 & -0.28 & 0.00 & 2023.18 & 85.76 & -40.02 & 0.12 \\
\hline Jing & 1.43 & 37.38 & -0.01 & 0.05 & 0.19 & 59.14 & 0.00 & 0.12 & 33.15 & 37.38 & -0.25 & 0.05 & 2614.30 & 59.14 & -50.98 & 0.12 \\
\hline Wei & 1.97 & 55.49 & -0.05 & 0.00 & 0.08 & 89.37 & 0.00 & 0.00 & 65.39 & 55.49 & -1.77 & 0.00 & 2376.23 & 89.37 & -108.53 & 0.00 \\
\hline Fen & 0.76 & 77.68 & -0.03 & 0.00 & 0.01 & 148.48 & 0.00 & 0.00 & 22.60 & 77.68 & -0.88 & 0.00 & 475.31 & 148.48 & -23.17 & 0.00 \\
\hline
\end{tabular}


Table 4

Selected policy documents for sediment management from 1949 to 2010 (Wang et al., 2015).

\begin{tabular}{|c|c|}
\hline Code & Policy \\
\hline P1 & $\begin{array}{l}\text { Directive to inform the population of drought control and drought } \\
\text { resistance measures and the popularization of soil and water conservation }\end{array}$ \\
\hline P2 & The decision to harness the Yellow River in 1953 \\
\hline P3 & $\begin{array}{l}\text { Summary of the water conservancy in the last four years and future policies } \\
\text { and tasks }\end{array}$ \\
\hline P4 & $\begin{array}{l}\text { Working report of the investigation mission regarding soil and water } \\
\text { conservation in northwest China of (draft) }\end{array}$ \\
\hline P5 & $\begin{array}{l}\text { The decision to integrate planning for radical solutions for disasters and } \\
\text { exploration of the water conservancy of the Yellow River }\end{array}$ \\
\hline P6 & $\begin{array}{l}\text { The provisional outline of soil and water conservation of the People's } \\
\text { Republic of China }\end{array}$ \\
\hline P7 & $\begin{array}{l}\text { The soil and water conservation planning in the middle reaches of the } \\
\text { Yellow River from } 1958 \text { to } 1962 \text { (draft) }\end{array}$ \\
\hline P8 & Report on the strengthening of soil and water conservation \\
\hline P9 & $\begin{array}{l}\text { Decision on soil and water conservation in the middle reaches of the Yellow } \\
\text { River }\end{array}$ \\
\hline P10 & Act of soil and water conservation at the small watershed scale \\
\hline P11 & Regulations on the work of water and soil conservation \\
\hline P12 & $\begin{array}{l}\text { The provisional rule to strengthen the soil and water conservation in key } \\
\text { areas of water and soil loss }\end{array}$ \\
\hline P13 & The ten policies to further develop the rural economy \\
\hline P14 & Law of The People's Republic of China on Water and Soil Conservation \\
\hline P15 & $\begin{array}{l}\text { Implementation of the law of the People's Republic of China regarding soil } \\
\text { and water conservation }\end{array}$ \\
\hline P16 & National plan for eco-environmental improvement \\
\hline P17 & National program for eco-environmental protection \\
\hline P18 & Regulations on conversion of farmland to forest \\
\hline P19 & Circular of policy on conversion of farmland to forest \\
\hline
\end{tabular}

the Fenhe experienced the largest reduction of $>60 \%$, with the two variables being significantly correlated $(r=0.87, p<0.001)$.

\section{Discussion}

\subsection{Driving forces}

Precipitation is the only source of water and the most important erosion force on the LP (Jia et al., 2015). Here, water yield capacity mainly refers to runoff coefficients. The runoff coefficients in the flood and non-flood seasons have both decreased between the two periods pre and post the change point in the annual streamflow series (Liang et al., 2015). Both the sediment identity and Budyko framework methods have consistently demonstrated that human ecological restoration activities on average contribute much more than climate change to streamflow reduction. This is also consistent with the results of previous studies, which have highlighted the importance of human ecological restoration measures for modifying the hydrological partitioning in the region (Miao and Ni, 2009; Wang et al., 2006; Yu et al., 2013; Wang et al., 2015; Gao et al., 2016; Wang et al., 2016).

This important transition has been influenced by both regional climate change and human activities. We investigated changes in the precipitation regime, including annual precipitation and annual heavy precipitation (i.e., daily rainfall events $>25 \mathrm{~mm}$ ) for the LP area and the tributaries. We found that annual precipitation was more strongly correlated with sediment flux than annual heavy precipitation ( $r=0.75$ and $r=0.51$, respectively, $p<0.01$ ), and that annual heavy precipitation remained approximately stable over the past 60 years (slope $=0.65 \mathrm{~mm}_{\text {year }}{ }^{-2}, p>0.1$ ). Therefore, we used annual precipitation in the identity analysis to quantify the effects of precipitation change on the decrease in sediment load. Based on the simple attribution approach, sediment identity is analogous to the Kaya identity in economics (Raupach et al., 2007), with the results showing that during recent decades, decreasing precipitation contributed less than $r$ and $s$ to the changes in water and sediment flux in the LP and the main tributaries. Even though the LP has experienced a significant warming over the last 60 years (Wang et al., 2012), it can be concluded that the human contribution has become increasingly more important for the YR hydrological regime transformation than climate drivers, which is the consensus of many other studies in this area (Miao et al., 2011; Mu et al., 2012; Wang et al., 2007; Zhao et al., 2013). Human restoration measures were implicitly integrated in the changes of $r$ and $s$ in the sediment identity (Zhang et al., 2015). Independent data regarding each of these measures suggest that the addition of civil engineering structures, terracing, and the construction of check dams and reservoirs were the main factors reducing the sediment load from the 1970s to 1990s (Liang et al., 2015; Zhang et al., 2015; Wang et al., 2016). In this century, large-scale vegetation restoration projects, i.e., "ecosystem engineering", have also reduced soil erosion at source (Chen et al., 2015; Wang et al., 2016). The results of the stepwise regression analysis also suggested that terrace and checkdam construction and annual precipitation were the two dominant factors associated with the decrease of river discharge from the 1960 s to 1999 , with re-vegetation becoming important during the 1990s-2000s. Therefore, human restoration measures in the LP have contributed to the reduced YR sediment load from this part of the catchment, which controls most of the total sediment load of the river. It should be noted that anthropogenic interventions also
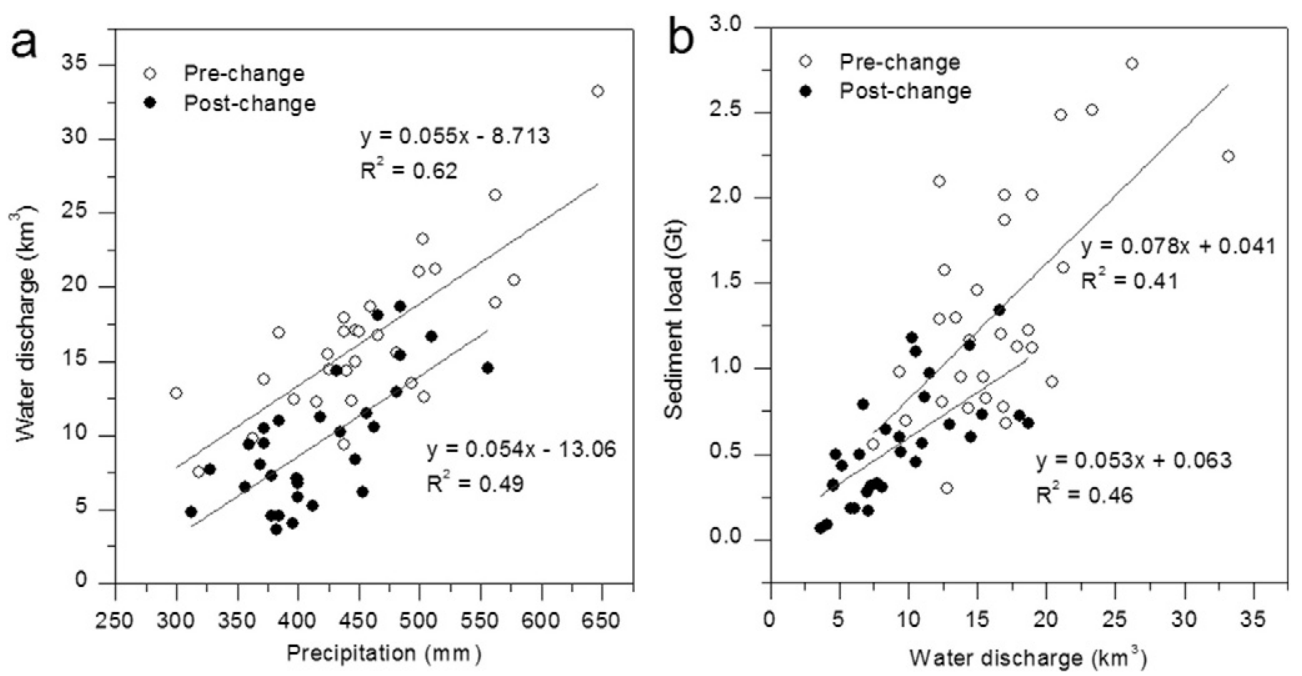

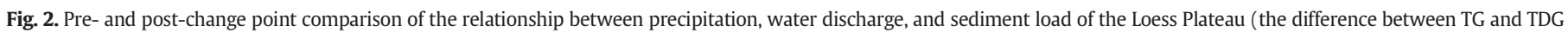
stations). a, precipitation with water discharge. b, water discharge with sediment load. 
a
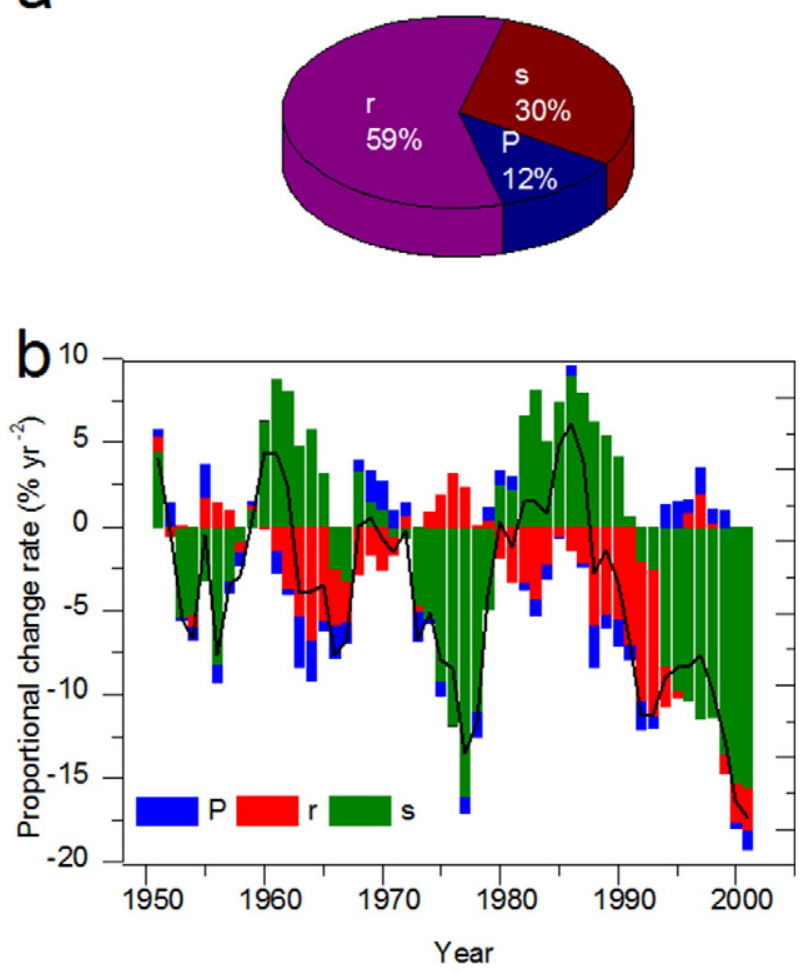

Fig. 3. Driving forces of sediment reduction and its dynamic processes on the Loess Plateau (the difference between TG and TDG stations). a, the relative contributions of precipitation (P), water yield capacity ( $\mathrm{r}$ ) and sediment concentration in river flow (s) to the sediment load reductions after the change point using the sediment identity. b, the dynamic processes contributing to sediment reduction.

include increasing water consumption and the effects of multiple dams (Bi et al., 2014; Wang et al., 2006; Yu et al., 2013).

\subsection{Policy effects}

These intensive engineering and vegetation projects are the result of the implementation of the various soil and water conservation or sediment control polices (Zhao et al., 2015) (Fig. 8). The occurrence of this change point in 1979 is reasonable because it is consistent with the beginning of the effective small watershed integrated control policy in this area. From the relationship between cumulative precipitation with cumulative water discharge and cumulative sediment load on the LP, we found that the amount of sediment mobilized by a given amount of precipitation was obviously influenced by the development polices. For example, $450 \mathrm{~mm}$ of precipitation on the LP in 1966 produced $2.11 \mathrm{Gt}$ of sediment load in the LP, whereas the same level of precipitation in 1992 produced only $0.99 \mathrm{Gt}$. After 1999, the ability of precipitation to produce water discharge and sediment load further decreased as the slope for the relationship between cumulative sediment load and cumulative precipitation became smoother. These policies have been implemented in various stages, with continuous adjustments and supplements. Since the foundation of the new China in 1949, there has been a policy to transform the YR from a harmful to beneficial river, and several associated soil and water conservation policies have been implemented (Zhao et al., 2013). However, under the "Great Leap forward Movement" from 1958 to 1960 and the "Emulating Dazhai on Agriculture Campaign" from 1964 to 1978 , crop land has expanded onto slopes, and deforestation and over grazing has weakened the effectiveness of the policies (Mu et al., 2012). After the change point year of 1979 , the social economy of
China developed rapidly following the implementation of the reform and opening-up policy. Small watershed integrated control policies have been implemented to combine the management of hills, water, forests, and cropland, with the aim of reducing sediment and flooding, and improving production (Zhao et al., 2015). Thus, engineering measures, especially terrace farming, reservoirs, and the dams built during this period have significantly contributed to the water and sediment reduction, but the effects of these measures have gradually weakened (Liang et al., 2015). With the economic improvement in China since 1999, the government has used administrative, legal, and financial approaches alongside various technologies to implement large projects such as the "Grain for Green Project" and "Eco-environmental construction of China" (Lü et al., 2012). This has led to a doubling of the vegetation cover in the LP and has significantly reduced the amount of both water and sediment in the YR (Liang et al., 2015). In the future, vegetation will play a larger role in soil and water conservation in this area (Zhang et al., 2015). The maintenance of a healthy and sustainable vegetated ecosystem is crucial for effective soil and water conservation. Therefore, a careful evaluation of the carrying capacity of the vegetation, as well as the selection of appropriate species and planting locations, is extremely important in this arid and semi-arid area.

In rivers, a reduced sediment load is usually welcomed because it can improve water quality, aquatic habitats, navigation, and reduces flood problems, especially for the heavily laden YR. However, reduced sediment loads can also give rise to problems, such as the scouring of river channels and the erosion of delta shorelines when the critical shear stress threshold is exceeded, as well as reducing nutrient inputs into aquatic and riparian ecosystems (Bi et al., 2014; Peng et al., 2010). The new discharge regime of the YR now has a series of geological and ecological implications for the coastal environment. The average rate of increase in shoreline length and delta area over the period of 1976-1985 decreased to 0.80 from $3.63 \mathrm{~km}$ year $^{-1}$ and 3.94 from $16.26 \mathrm{~km}^{2}$ year ${ }^{-1}$, respectively (Yu et al., 2011). This reduction in sediment supply to the lower reach and estuary has already resulted in the YR delta shifting to an erosional phase, potentially affecting more than two million people (Zhou et al., 2015). In addition, the reduced material supply could also lead to a series of ecological responses in the Bohai Sea (Peng et al., 2010). Previous studies have estimated the threshold to maintain the balance of the delta is $159 \times 10^{6} \mathrm{t}$ sediment load per year after the lower YR channel changed in 1996. This can be satisfied and kept relatively stable since the implementation of the watersediment regulation scheme since 2002 (Kong et al., 2015). It is important to conserve soil and minimize the impact of sediment of river water in the middle reach of the YR because the watersediment regulation scheme is no longer as effective as it initially

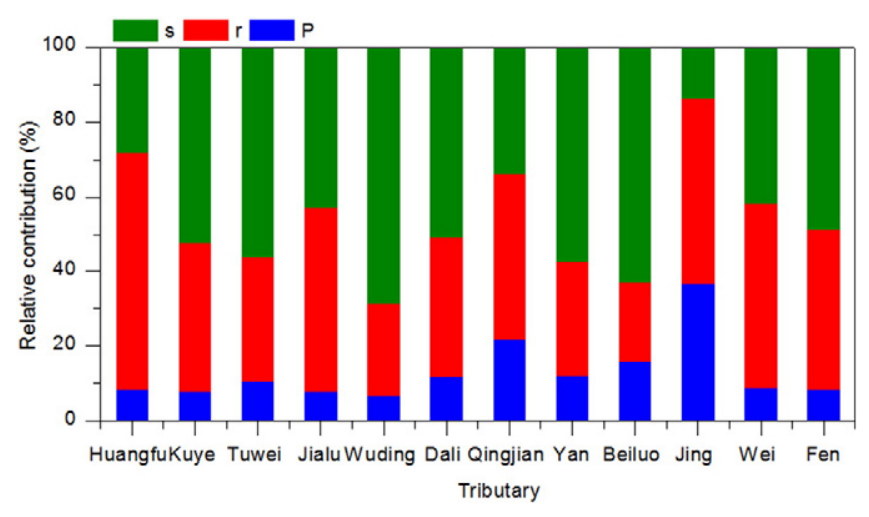

Fig. 4. Spatial variability of the driving forces of sediment reduction on the Loess Plateau, including the relative contributions of precipitation $(P)$, water yield capacity $(r)$ and sediment concentration in river flow (s) to the sediment load reductions. 


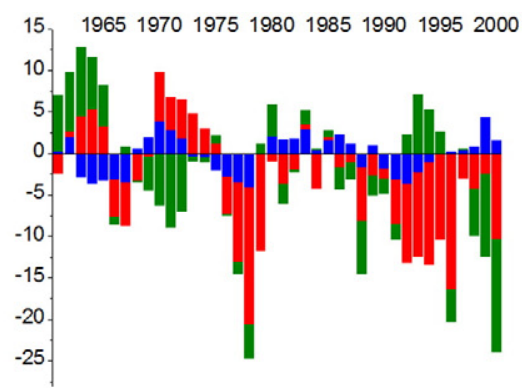

Kuye
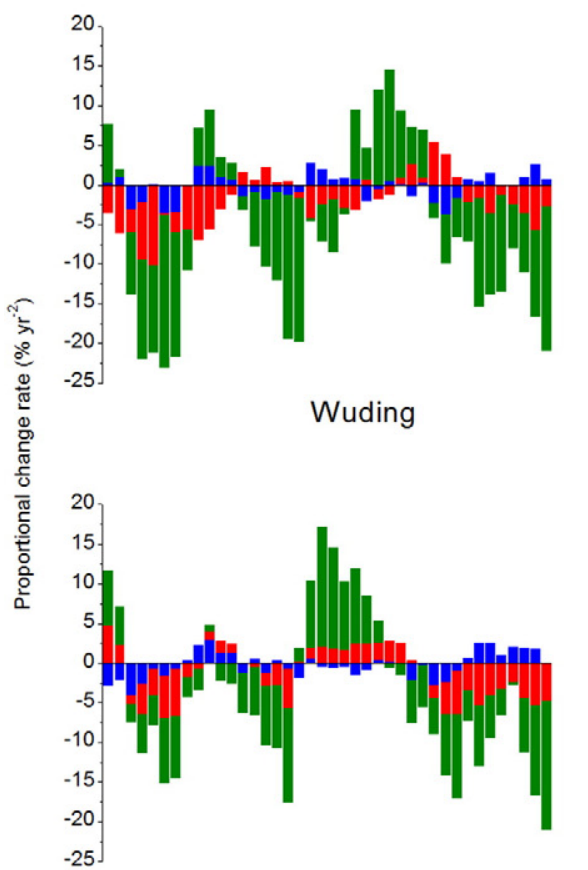

Yanhe

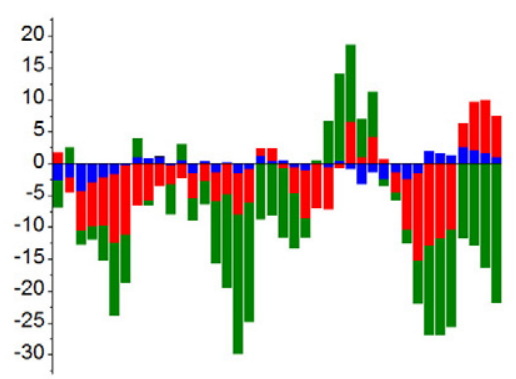

Fenhe

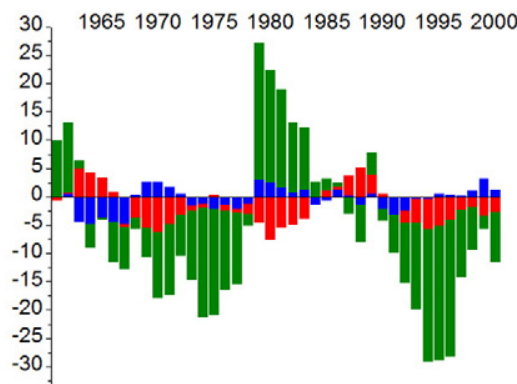

Tuwei

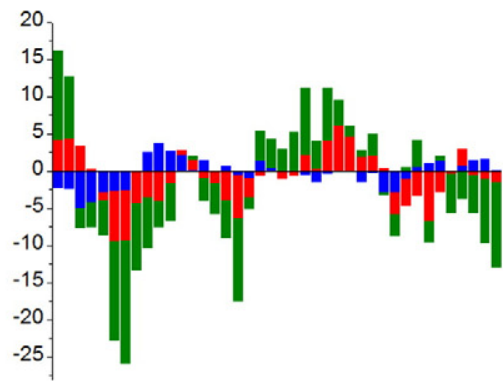

Dali

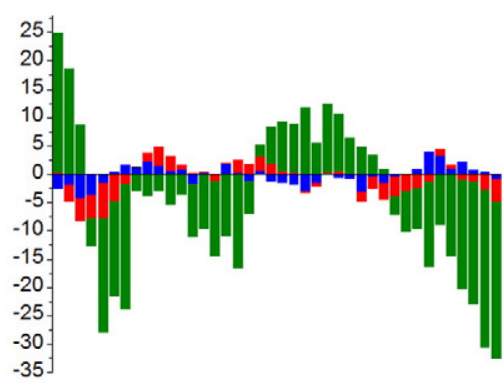

Beiluo

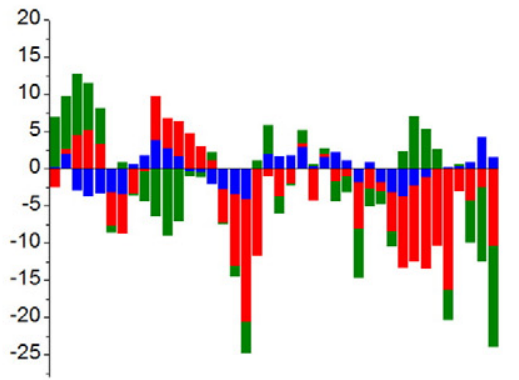

Huangfu

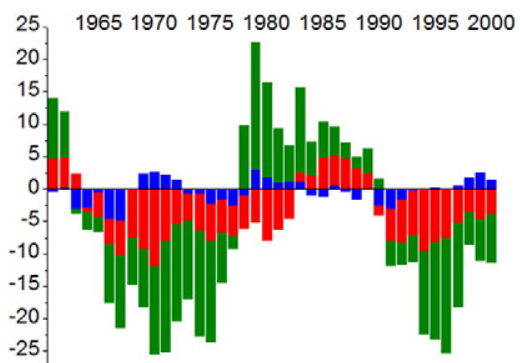

Jialu

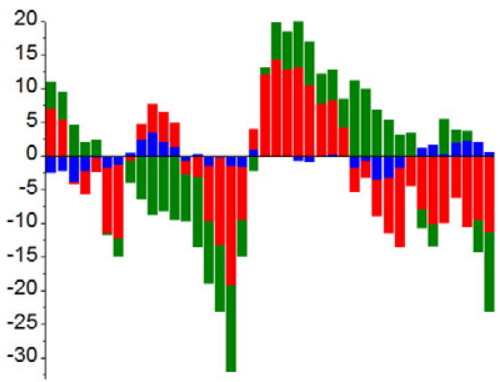

Qingjian

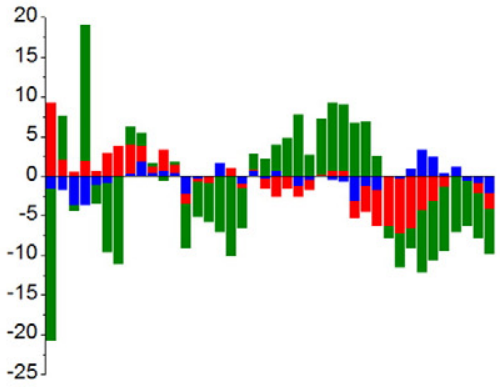

Jinghe

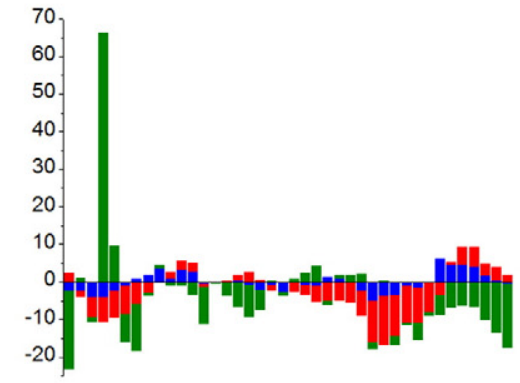

Weihe

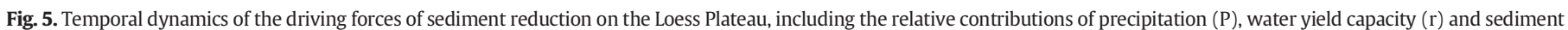
concentration in river flow $(\mathrm{s})$ to the sediment load reductions.

was for the lower YR (Miao et al., 2016). The YR Delta is an important region because of its location and unique ecological environment, and it is important to meet the challenge of increasing water demand and avoid the sediment siltation in the lower river. Although the YR has been kept less "yellow", it is also necessary to consider the water and material needs of downstream users and the consequences of river drying and delta erosion. Therefore, a strategic plan for the whole-basin is needed to maximize the benefits, but reduce the risks for both catchment ecosystems and the humans who reside there.

\section{Conclusion}

Harmonizing the relationship between water and sediment has always been the most difficulty aspect of YR management. Effective soil conservation on the LP is critical for sustainably harnessing the YR. We found that the sharp (58\%) reduction of sediment after 1979 was mainly (59\%) caused by a water yield decrease. Engineering and vegetation measures have induced land surface modifications, which are responsible for $76 \%$ of the water reduction. These measures have been implemented as part of a coordinated set of soil and water conservation, 


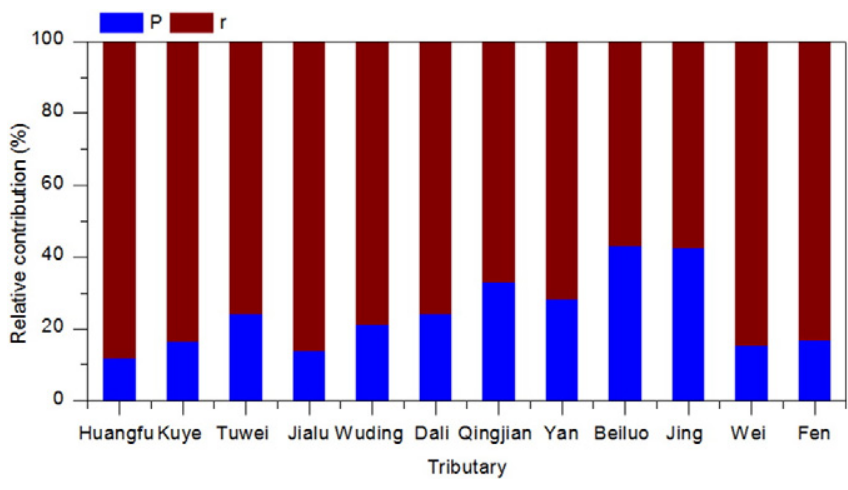

Fig. 6. Contributions of precipitation and water yield capacity to changes in water discharge for the main tributaries on the Loess Plateau.

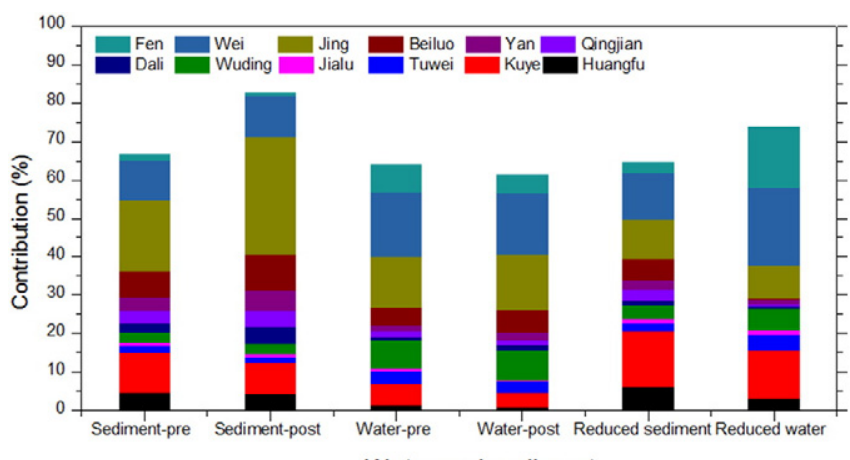

Water and sediment

Fig. 7. The contribution of the tributaries to water and sediment generation pre and post the change point year (1979).

and sediment control polices. Decades of effort have reverted the YR sediment load to a pre-human (around $600 \mathrm{CE}$ ) near-pristine level, and now is a good time to take stock of what has been achieved. The YR is the most manipulated fluvial system in the world, but there is a tradeoff between soil conservation in the middle reach and water demand in the lower reach. To control the sediment yield and its effect on river water in the LP, we propose the cessation of construction and the maintenance of a sustainable vegetated ecosystem (i.e., low water consumption) on the LP for soil conservation, as well as the establishment of an integrated basin-wide ecosystem and land use management mechanism for sustainable water and sediment regulation. These strategies would together lead to a harmonious relationship between water

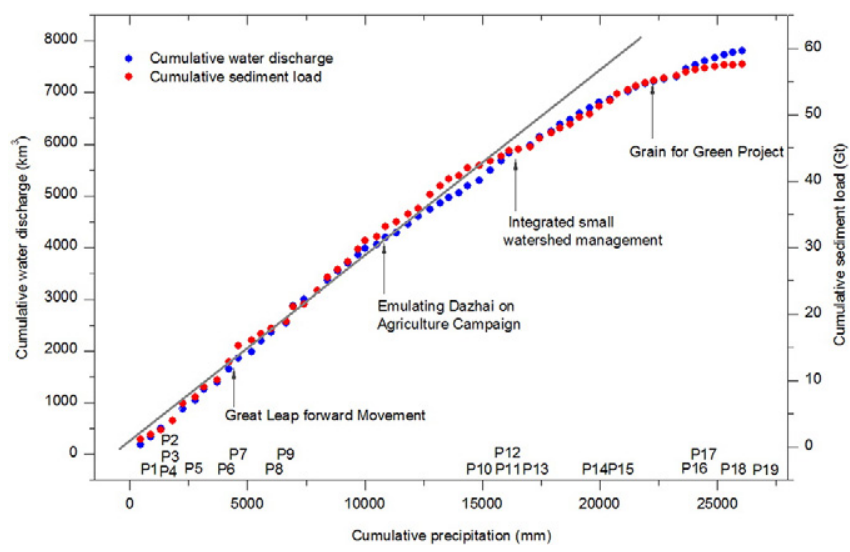

Fig. 8. The effects of government policies on water and sediment generation on the Loess Plateau, P indicates Policy Document No (see Table 4). and sediment for the YR, retaining the less "yellow" status and a healthy water quality.

\section{Acknowledgements}

This work was funded by the National Natural Science Foundation of China (No. 41561134016, 41390464, 41401027), and the Chinese Academy of Sciences (No. GJHZ 1502). We thank Prof. John Gash for his assistance with the English language editing.

\section{References}

Bi, N., Wang, H., Yang, Z., 2014. Recent changes in the erosion-accretion patterns of the active Huanghe (Yellow River) delta lobe caused by human activities. Cont. Shelf Res. 90, 70-78.

Chen, Y., Wang, K., Lin, Y., Shi, W., Song, Y., He, X., 2015. Balancing green and grain trade. Nat. Geosci.

Downs, P.W., Gregory, K.J., Brookes, A., 1991. How integrated is river basin management? Environ. Manag. 15 (3), 299-309.

Gao, P., et al., 2016. Dynamic sediment discharge in the Hekou-Longmen region of Yellow River and soil and water conservation implications. Sci. Total Environ. http://dx.doi. org/10.1016/j.scitotenv.2016.06.128.

Jia, X., Xie, B., Shao, M.a., Zhao, C., 2015. Primary productivity and precipitation-use efficiency in temperate grassland in the loess plateau of China. PLoS One 10 (8), e0135490.

Kantoush, S.A., Sumi, T., 2010. River morphology and sediment management strategies for sustainable reservoir in Japan and European Alps. Ann. Disaster Prev. Res. Inst., Kyoto Univ. 53, 821-839.

Kong, D., Miao, C., Wu, J., Duan, Q., Sun, Q., Ye, A., Di, Z., Gong, W., 2015. The hydroenvironmental response on the lower Yellow River to the water-sediment regulation scheme. Ecol. Eng. 79, 69-79.

Lü, Y., Fu, B., Feng, X., Zeng, Y., Liu, Y., Chang, R., Sun, G., Wu, B., 2012. A policy-driven large scale ecological restoration: quantifying ecosystem services changes in the Loess Plateau of China. PLoS One 7 (2), e31782.

Liang, W., Bai, D., Wang, F., Fu, B., Yan, J., Wang, S., Yang, Y., Long, D., Feng, M., 2015. Quantifying the impacts of climate change and ecological restoration on streamflow changes based on a Budyko hydrological model in China's Loess Plateau. Water Resour. Res. 51 (8), 6500-6519.

Liu, X., Yang, S., Dang, S., Luo, Y., Li, X., Zhou, X., 2014. Response of sediment yield to vegetation restoration at a large spatial scale in the Loess Plateau. China Technological Sciences]->SCIENCE CHINA Technol. Sci. 57 (8), 1482-1489.

Miao, C., Ni, J., Borthwick, A.G., 2010. Recent changes of water discharge and sediment load in the Yellow River basin, China. Prog. Phys. Geogr. 34 (4), 541-561.

Miao, C., Ni, J., Borthwick, A.G.L., Yang, L., 2011. A preliminary estimate of human and natural contributions to the changes in water discharge and sediment load in the Yellow River. Glob. Planet. Chang. 76 (3-4), 196-205.

Miao, C., Ni, J.R., 2009. Variation of natural streamflow since 1470 in the middle Yellow River, China. J Environ Res Public Health]->Int. J. Environ. Res. Public Health 6 (11), 2849-2864.

Miao, C., Kong, D., Wu, J., Duan, Q., 2016. Functional degradation of the water-sediment regulation scheme in the lower Yellow River: spatial and temporal analyses. Sci. Total Environ. 551-552, 16-22.

Mu, X., Zhang, X., Shao, H., Gao, P., Wang, F., Jiao, J., Zhu, J., 2012. Dynamic changes of sediment discharge and the influencing factors in the Yellow River, China, for the recent 90 years. CLEAN: Soil, Air, Water 40 (3), 303-309.

Peng, J., Chen, S., Dong, P., 2010. Temporal variation of sediment load in the Yellow River basin, China, and its impacts on the lower reaches and the river delta. Catena 83 (23), 135-147.

Piao, S., Friedlingstein, P., Ciais, P., de Noblet-Ducoudré, N., Labat, D., Zaehle, S., 2007. Changes in climate and land use have a larger direct impact than rising $\mathrm{CO} 2$ on global river runoff trends. Proc. Natl. Acad. Sci. 104 (39), 15242-15247.

Raupach, M.R., Marland, G., Ciais, P., Le Quéré, C., Canadell, J.G., Klepper, G., Field, C.B., 2007. Global and regional drivers of accelerating $\mathrm{CO}_{2}$ emissions. Proc. Natl. Acad. Sci. 104 (24), 10288-10293.

Syvitski, J.P., 2003. Supply and flux of sediment along hydrological pathways: research for the 21st century. Glob. Planet. Chang. 39 (1), 1-11.

Syvitski, J.P., Kettner, A., 2011. Sediment flux and the anthropocene. Philosophical transactions of the Royal Society of London a: mathematical. Phys. Eng. Sci. 369 (1938), 957-975.

Walling, D.E., 2009. The impact of global change on erosion and sediment transport by rivers: current progress and future challenges. UNESCO.

Walling, D.E., Fang, D., 2003. Recent trends in the suspended sediment loads of the world's rivers. Glob. Planet. Chang. 39 (1-2), 111-126.

Wang, F., Mu, X.M., Li, R., Fleskens, L., Stringer, L.C., Ritsema, C.J., 2015. Co-evolution of soil and water conservation policy and human-environment linkages in the Yellow River Basin since 1949. Sci. Total Environ. 508, 166-177.

Wang, H., Yang, Z., Saito, Y., Liu, J.P., Sun, X., 2006. Interannual and seasonal variation of the Huanghe (Yellow River) water discharge over the past 50 years: connections to impacts from ENSO events and dams. Glob. Planet. Chang. 50 (3-4), 212-225.

Wang, H., Yang, Z., Saito, Y., Liu, J.P., Sun, X., Wang, Y., 2007. Stepwise decreases of the Huanghe (Yellow River) sediment load (1950-2005): impacts of climate change and human activities. Glob. Planet. Chang. 57 (3-4), 331-354. 
Wang, Q.-X., Fan, X.-h., Qin, Z.-d., Wang, M.-b., 2012. Change trends of temperature and precipitation in the Loess Plateau Region of China, 1961-2010. Glob. Planet. Chang. 92, 138-147.

Wang, S., Fu, B., Piao, S., Lü, Y., Philippe, C., Feng, X., Wang, Y., 2016. Reduced sediment transport in the Yellow River due to anthropogenic changes. Nat. Geosci. 9, 38-41.

Wohl, E., 2006. Human impacts to mountain streams. Geomorphology 79 (3), 217-248.

Yu, J., Fu, Y., Li, Y., Han, G., Wang, Y., Zhou, D., Sun, W., Gao, Y., Meixner, F., 2011. Effects of water discharge and sediment load on evolution of modern Yellow River Delta, China, over the period from 1976 to 2009. Biogeosciences 8, 2427-2435.

Yu, Y., Wang, H., Shi, X., Ran, X., Cui, T., Qiao, S., Liu, Y., 2013. New discharge regime of the Huanghe (Yellow River): causes and implications. Cont. Shelf Res. 69, 62-72.
Zhang, C., Liu, G.B., Xue, S., Wang, G.L., 2015. Changes in rhizospheric microbial community structure and function during the natural recovery of abandoned cropland on the Loess Plateau, China. Ecol. Eng. 75, 161-171.

Zhao, G., Mu, X., Wen, Z., Wang, F., Gao, P., 2013. Soil erosion, conservation, and ecoenvironment changes in the loess plateau of China. Land Degrad. Dev. (n/a-n/a).

Zhao, W.J., Zhang, Y., Zhu, Q.K., Qin, W., Peng, S.Z., Li, P., Zhao, Y.M., Ma, H., Wang, Y., 2015. Effects of microtopography on spatial point pattern of forest stands on the semi-arid Loess Plateau, China. J. Arid. Land 7 (3), 370-380.

Zhou, Y., Huang, H.Q., Nanson, G.C., Huang, C., Liu, G., 2015. Progradation of the Yellow (Huanghe) River delta in response to the implementation of a basin-scale water regulation program. Geomorphology 243, 65-74. 